University of Nebraska - Lincoln

DigitalCommons@University of Nebraska - Lincoln

USDA National Wildlife Research Center - Staff Publications
U.S. Department of Agriculture: Animal and Plant Health Inspection Service

2021

\title{
Diets of double-crested cormorants in the Lake Winnebago System, Wisconsin
}

\author{
Ryan P. Koenigs \\ Wisconsin Department of Natural Resources, Ryan.koenigs@wisconsin.gov \\ Daniel J. Dembkowski \\ University of Wisconsin- Stevens Point, dan.dembkowski@uwsp.edu \\ Charles D. Lovell \\ United States Department of Agriculture, National Wildlife Research Center, \\ charles.d.lovell@aphis.usda.gov \\ Daniel A. Isermann \\ University of Wisconsin-Stevens Point, dan.isermann@uwsp.edu \\ Adam D. Nickel \\ Wisconsin Department of Natural Resources, Adam.Nickel@wisconsin.gov \\ Follow this and additional works at: https://digitalcommons.unl.edu/icwdm_usdanwrc \\ Part of the Natural Resources and Conservation Commons, Natural Resources Management and \\ Policy Commons, Other Environmental Sciences Commons, Other Veterinary Medicine Commons, \\ Population Biology Commons, Terrestrial and Aquatic Ecology Commons, Veterinary Infectious Diseases \\ Commons, Veterinary Microbiology and Immunobiology Commons, Veterinary Preventive Medicine, \\ Epidemiology, and Public Health Commons, and the Zoology Commons
}

Koenigs, Ryan P.; Dembkowski, Daniel J.; Lovell, Charles D.; Isermann, Daniel A.; and Nickel, Adam D., "Diets of double-crested cormorants in the Lake Winnebago System, Wisconsin" (2021). USDA National Wildlife Research Center - Staff Publications. 2436.

https://digitalcommons.unl.edu/icwdm_usdanwrc/2436

This Article is brought to you for free and open access by the U.S. Department of Agriculture: Animal and Plant Health Inspection Service at DigitalCommons@University of Nebraska - Lincoln. It has been accepted for inclusion in USDA National Wildlife Research Center - Staff Publications by an authorized administrator of DigitalCommons@University of Nebraska - Lincoln. 


\title{
Diets of double-crested cormorants in the Lake Winnebago System, Wisconsin
}

\author{
Ryan P. Koenigs $^{1}$ (D) | Daniel J. Dembkowski ${ }^{2}$ | Charles D. Lovell ${ }^{3}$ | Daniel A. Isermann ${ }^{4}$ | \\ Adam D. Nickel ${ }^{1}$
}

${ }^{1}$ Wisconsin Department of Natural Resources, Bureau of Fisheries Management, Oshkosh, WI, USA

${ }^{2}$ Wisconsin Cooperative Fishery Research Unit, Fisheries Analysis Center, College of Natural Resources, University of WisconsinStevens Point, Stevens Point, WI, USA

${ }^{3}$ U.S. Department of Agriculture, Animal and Plant Health Inspection Service, Wildlife Services, Waupun, WI, USA

${ }^{4}$ U.S. Geological Survey, Wisconsin Cooperative Fishery Research Unit, College of Natural Resources, University of Wisconsin-Stevens Point, Stevens Point, WI, USA

\section{Correspondence}

Ryan P. Koenigs, Wisconsin Department of Natural Resources, Oshkosh, Wisconsin, USA.

Email: Ryan.koenigs@wisconsin.gov

Funding information

Great Lakes Restoration Initiative

\begin{abstract}
Double-crested cormorant Phalacrocorox auritus Lesson (cormorant) populations have increased throughout the Great Lakes region of North America causing concern related to the impact of cormorant predation on fish communities. A recent decline in yellow perch Perca flavescens (Mitchill) abundance within the Lake Winnebago System, Wisconsin, USA, prompted an assessment of cormorant diets to evaluate potential effects of cormorant predation on the sportfish community. Diets were collected from 883 cormorants ( 417 from Lake Winnebago and 466 from Lake Butte des Morts) between 2015 and 2017. Cormorant diets on both waterbodies consisted mostly of freshwater drum Aplodinotus grunniens Rafinesque and gizzard shad Dorosoma cepedianum (Lesueur). Yellow perch and walleye Sander vitreus (Mitchill) observations were infrequent and represented $<5 \%$ of cormorant diets by weight each year. Under current conditions, cormorant predation likely has minimal impact on the Lake Winnebago sportfish community, but more research is needed to assess potential impacts on Lake Butte des Morts.
\end{abstract}

\section{KEYWORDS}

cormorant consumption, cormorant diet

\section{1 | INTRODUCTION}

Double-crested cormorant Phalacrocorax auritus Lesson (referred to as "cormorant" hereafter) populations in the U.S. have increased dramatically in recent decades, mainly due to their protection under the Migratory Bird Treaty Act as amended in 1972 and the banning of dichlorodiphenyltrichloroethane (DDT) in pesticides and herbicides (Wires \& Cuthbert, 2006). In the Great Lakes region, the breeding population of cormorants increased from approximately 21,000 to 76,000 nesting pairs between the early 1990s and 2000 (Weseloh et al., 2002). The expansion of cormorant populations throughout their range has renewed interest in assessing the influence of cormorant predation on fish populations and fishery resources (Johnson et al., 2015; King et al., 2017; Meadows, 2007; Rudstam et al., 2004).

Cormorants are opportunistic piscivores, and in some previous studies, percids, particularly yellow perch Perca flavescens
(Mitchill) and walleye Sander vitreus (Mitchill), have comprised the majority (at least within a season or year) of cormorant diets (Johnson et al., 2002, 2015; Meadows, 2007; Rudstam et al., 2004; Schultz et al., 2013). Conversely, other studies have reported that percids were present in cormorant diets, but other abundant, non-sport fishes including alewife Alosa pseudoharengus Wilson, gizzard shad Dorosoma cepedianum (Lesueur) and freshwater drum Aplodinotus grunniens Rafinesque were most prevalent (Belyea, 1997; Bur et al., 1997; Ross \& Johnson, 1997; Diana et al., 2006; King et al., 2017). Furthermore, round goby Neogobius melanostomus (Pallas) has become an important prey species for cormorants in areas of the Great Lakes with established goby populations (Coleman et al., 2012; Johnson et al., 2010, 2015). These studies highlight the adaptability of cormorants and demonstrate variability in foraging patterns depending on prevailing fish community characteristics. 
The effects of cormorant predation on fish populations and fishery resources encompass a broad spectrum, ranging from minimal impacts to substantial losses. For instance, Craven and Lev (1987) reported that losses of lake whitefish Coregonus clupeaformis (Mitchill) from the Lake Superior commercial fishery were not attributed to direct predation, but rather to a behavioural response of the fish to cormorant presence. Furthermore, Campo et al. (1993) concluded that sport fishes (e.g. largemouth bass Micropterus salmoides Lacepède and channel catfish Ictalurus punctatus Rafinesque) contributed an insignificant proportion of diets collected from wintering cormorants in Texas reservoirs. By contrast, cormorant predation was likely the dominant source of subadult mortality for walleye and yellow perch in Oneida Lake, New York, which was believed to be a major factor contributing to the declining walleye and yellow perch populations (Rudstam et al., 2004; VanDeValk et al., 2002). The estimated revenue lost in the Oneida Lake Region due to cormorant damage was estimated at US\$6.7 million to US\$33.3 million annually between 1990-2005
(Shwiff et al., 2009). Similar negative impacts were observed for the Les Cheneaux Islands region of Lake Huron where yellow perch abundance, recruitment and angler harvest increased in response to declining cormorant abundance, suggesting a strong predatory influence on the perch population prior to the onset of cormorant population abatement activities in 2004 (Fielder, 2008, 2010). Based on the variable impacts of cormorant predation reported in the literature, system-specific evaluations of potential impacts of cormorant predation are often warranted.

Located in east-central Wisconsin, the Lake Winnebago System consists of lakes Winnebago, Butte des Morts, Winneconne and Poygan, which collectively cover 66,843 ha of water (Figure 1 ). The system is home to socially and economically important fisheries consisting of walleye, yellow perch, black crappie Pomoxis nigromaculatus (Lesueur), largemouth bass, smallmouth bass Micropterus dolomieu Lacepède, white bass Morone chrysops (Rafinesque) and lake sturgeon Acipenser fulvescens (Rafinesque). The non-sturgeon, year-round recreational fishery on the Lake Winnebago System is

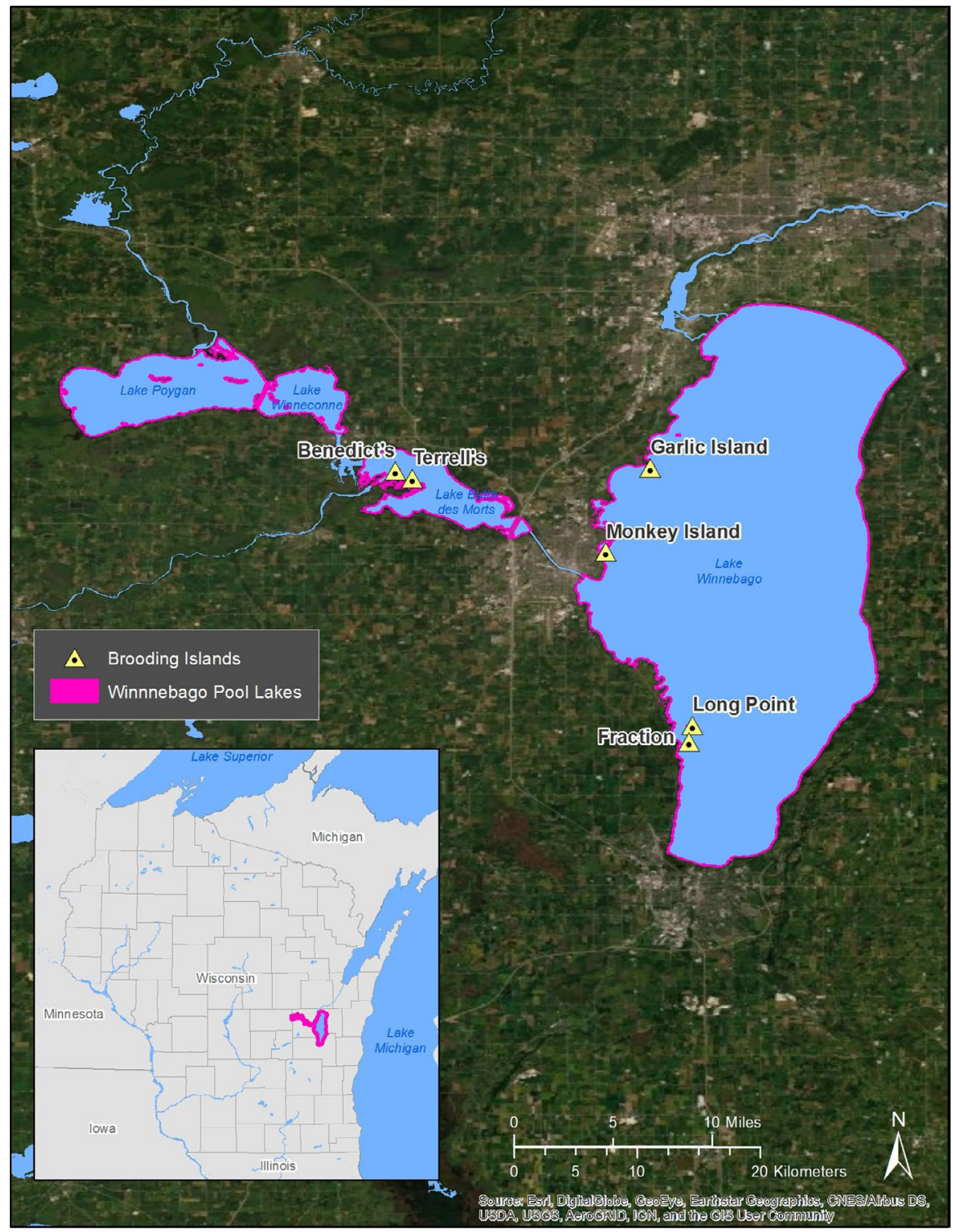

FIGURE 1 Map of the Lake Winnebago System Pool Lakes with known cormorant nesting colonies on Lake Winnebago (Garlic Island, Monkey Island, Long Point Island and Fraction Islands) and Lake Butte des Morts (Terrell's Island and Benedict's Island) identified [Colour figure can be viewed at wileyonlinelibrary.com] 
estimated to contribute US $\$ 234$ million towards local economies each year (Cook \& Neiswender, 2007).

Cormorant colonies throughout the Lake Winnebago System expanded concurrently with other breeding populations in the Great Lakes, and cormorant management activities on the Lake Winnebago System began in 2008. Monitoring and management initiatives included annual nest counts, egg oiling and lethal removal. Egg oiling and lethal removal ceased in 2016 following a court order; however, birds were lethally collected in 2016 and 2017 under a scientific collector's permit to support the current study. Despite system-wide reductions in cormorant populations stemming from abatement activities (Table 1), there remains an opinion among angler groups that cormorant predation may be depleting fish populations. This, combined with the demonstrated ability of cormorant populations to influence fishery resources negatively (e.g. Fielder, 2008, 2010; Rudstam et al., 2004) and a recent decline in yellow perch abundance, prompted concern among resource users and managers that cormorants may be negatively influencing fish communities and recreational angling opportunities within the Lake Winnebago System. However, feeding ecology of cormorants on the Lake Winnebago System is unknown, as is the potential influence of cormorant predation on fisheries resources. Consequently, the objective was to determine if diet composition of cormorants varied seasonally. These seasonal consumption estimates were then used to define a likely range of cormorant consumption on recreationally and ecologically important fishes (yellow perch and walleye) in the Lake Winnebago System.

\section{2 | METHODS}

The number of active cormorant nests at known nesting sites throughout the Lake Winnebago System was counted annually by United States Department of Agriculture Wildlife Services (USDA WS) staff from 2008-2017 following protocols outlined by Cuthbert and Wires (2013). Nesting locations monitored included Garlic Island, Monkey Island, Long Point Island, and the Fraction Islands on Lake Winnebago and Terrell's Island and Benedict's Island on Lake Butte des Morts (Figure 1; Table 1). There were no known cormorant nesting colonies on lakes Winneconne or Poygan during the study period. A minimum of three nest counts were taken on foot within each colony annually and included a complete census of nests present from ground- and tree-nesting birds. Because the total number of nests observed during multiple visits to each island changed due to asynchronous nesting, the peak nest number was used to determine the cormorant population at each nesting site as per guidance by Cuthbert and Wires (2013).

Diet sampling occurred throughout the period that cormorants were present at nesting colonies (April-September); however, it was difficult to collect cormorants during the post-nesting phase in 2015 and 2016, particularly from Lake Winnebago. As part of population control measures, cormorants were shot by USDA WS technicians using 12-gauge shotguns (non-toxic steel shot) with a target sample size of 30 birds per waterbody every two weeks. To assess seasonal variation in diet composition, data collected throughout the residence period were pooled into three groups to represent early(April-May), mid- (June-July) and late-summer (August-September) periods.

Identification of diet items occurred within one hour of death. Birds collected in April and May were not injected with alcohol as prey items were not observed in advanced stages of digestion. Prey items in diets collected from July-September were often in more advanced stages of digestion; therefore, isopropyl alcohol (70\%) was injected into the esophagus to slow decomposition and allow for easier identification of prey items. Each bird was weighed to the nearest $10 \mathrm{~g}$. Diet items were identified to species, enumerated and weighed for wet mass (g). Fish in early stages of digestion were individually weighed and measured, whereas unidentifiable prey fishes and miscellaneous fish parts were pooled as "unknown" prey items.

TAB LE 1 Number of active cormorant nests observed at known cormorant nesting colonies identified on Lake Winnebago and Lake Butte des Morts

\begin{tabular}{|c|c|c|c|c|c|c|c|c|}
\hline Year & \multicolumn{5}{|c|}{ Lake Winnebago } & \multicolumn{3}{|c|}{ Lake Butte des Morts } \\
\hline 2008 & & 577 & 1,832 & & 2,409 & & & \\
\hline 2009 & & 170 & 1,304 & & 1,474 & & & \\
\hline 2010 & & 0 & 988 & & 988 & & & \\
\hline 2013 & 0 & 48 & 0 & 194 & 242 & 252 & 1,211 & 1,463 \\
\hline 2014 & 0 & 0 & 120 & 96 & 216 & 8 & 1,485 & 1,493 \\
\hline 2015 & 0 & 0 & 190 & 0 & 190 & 0 & 516 & 516 \\
\hline 2016 & 0 & 0 & 125 & 0 & 125 & 0 & 454 & 454 \\
\hline
\end{tabular}

Note: Data collected by United States Wildlife Services staff (2008-2017). Blanks indicate that colonies were not sampled in given years. 
Relative abundance of sport and non-sport fish species in Lake Winnebago was assessed via annual bottom trawl assessments similar to methods described by Koenigs et al. (2015). Forty-six standardised locations were sampled three times each year (August, September and October). Sampling at each location consisted of pulling a balloon trawl (8.2-m head rope) along the bottom at a speed of $6.4 \mathrm{~km} / \mathrm{h}$ to cover roughly $0.4 \mathrm{ha}$. All fish captured in the survey were counted and sportfish (walleye, sauger Sander canadensis (Griffith \& Smith), white bass, channel catfish, lake sturgeon, yellow perch, black crappie and bluegill Lepomis macrochirus Rafinesque) were measured for total length (TL; nearest 0.1 inch). A random sample of 25 adult freshwater drum captured from roughly every third trawl was measured to the nearest 0.1 inch (TL). The bottom trawl is most effective at capturing young of year and yearling fish. However, fish of all life stages are captured in the trawl and this assessment provided a conservative relative density estimate for fish captured from Lake Winnebago during the study period. Density estimates from bottom trawling do not account for fish suspended off the bottom or gear avoidance; thus, catch data from trawling likely underestimate the actual fish density within the water body and, therefore, estimated impacts of cormorant predation on the sportfish community would be conservative.

\section{1 | Data analysis}

Cormorant diets for each lake, year and sampling period (i.e. early-, mid-, and late-summer) were summarised as:

$$
\mathrm{MW}_{i}=\frac{1}{P} \sum_{j=1}^{P}\left(\frac{W_{i j}}{\sum_{i=1}^{Q} W_{i j}}\right)
$$

where $\mathrm{MW}_{i}$ is the mean proportion by weight of prey type $i, P$ is the total number of cormorants with non-empty stomachs, $W$ is the weight ( $\mathrm{g}$ ) of prey type $I$ in an individual cormorant $j$, and $Q$ is the number of prey types $i$ in cormorant $j$ (Chipps \& Garvey, 2007). To determine if lake- and year-specific cormorant diets varied among sampling periods, $\mathrm{MW}_{i}$ was compared among early-, mid-, and late-summer periods using a multivariate analysis of variance $($ MANOVA; test statistic $=$ Wilks' $\Lambda$ ). Individual analyses of variance (ANOVA) were performed to identify which prey items varied among sampling periods when results from the MANOVA suggested an overall temporal effect. Bonferroni adjustments to alpha ( $\alpha=0.05 / n$; $n=$ number of pairwise comparisons) were used to reduce the possibility of committing a type I error.

Nest count data (Table 1; nest count x 2) and a seasonal residence time of 169 days (April 15-October 1 based on observations from USDA WS staff) were used to estimate the number of cormorant feeding days/ha on Lake Winnebago and Lake Butte des Morts. Annual consumption of fish by the breeding population of cormorants on each waterbody was estimated using a model similar to Johnson et al. (2002). The model incorporates the number of feeding days (cormorant population size and seasonal residence time) and daily ingestion rates. Because daily ingestion rates for cormorants collected in the Lake Winnebago System was not estimated, maximum (750 g/day; Schultz et al., 2013) and minimum (313 g/day; Meadows, 2007) daily ingestion rates reported in the literature were used to provide a likely range in consumption of fishes by cormorants. Although use of minimum and maximum reported ingestion rates is appropriate to estimate the likely range in consumption of fishes, consumption estimates are conservative in that the model does not account for consumption by immature cormorants, non-breeders or transient birds. However, feeding by young and immature cormorants within the Lake Winnebago System is minimal as extensive egg oiling practices have reduced recruitment (USDA WS, unpublished data). The number of non-breeding and transient birds using the Lake Winnebago System is unknown as the standard protocol for estimating colony size does not account for non-nesting birds (Cuthbert \& Wires, 2013). However, the overall impact of non-breeding birds is thought to be minimal relative to the consumption by the nesting colony on these lakes (Personal communication, USDA WS). Schultz et al. (2013) reported similar observations for Leech Lake, Minnesota where non-breeders and transient cormorants had minimal effect on overall consumption estimates.

Consumption of individual prey species was estimated by multiplying total consumption (based on minimum and maximum daily ingestion rates) by $\mathrm{MW}_{i}$ for each prey item in each lake and year. For example, if total consumption ranged from $800 \mathrm{~kg} / \mathrm{yr}$ to $1,000 \mathrm{~kg} /$ $\mathrm{yr}$ and freshwater drum comprised an average of $50 \%$ of diets by weight, consumption of freshwater drum ranged from $400 \mathrm{~kg} / \mathrm{yr}$ to $500 \mathrm{~kg} / \mathrm{yr}$. Biomass of prey species consumed was converted to number of fish consumed based on mean weight of individuals recovered from diets. To evaluate the potential influence of cormorant predation on fish populations in the Lake Winnebago System, consumption of individual prey species was expressed as the number of fish/ha and compared to life stage specific density estimates for the most important prey species estimated from bottom trawl assessments. Freshwater drum, white bass and yellow perch captured during autumn bottom trawl assessments were considered young of year if they were $<100 \mathrm{~mm}$ TL, while walleye were classified as young of year if they were $<200 \mathrm{~mm}$ TL when captured in the trawl (WDNR unpublished data). Yellow perch $>100$ but $<200 \mathrm{~mm}$ TL were classified as yearlings, while fish $>200 \mathrm{~mm}$ TL were classified as age- 2 and older. Walleye $>200 \mathrm{~mm}$ but $<300 \mathrm{~mm}$ TL were classified as yearlings and walleye $>300 \mathrm{~mm}$ TL were classified as age-2 and older (WDNR unpublished data). Freshwater drum and white bass larger than $100 \mathrm{~mm}$ TL were classified as yearling and older.

\section{3 | RESULTS}

Diet data were collected for 883 cormorants (351 in 2015, 218 in 2016 and 314 in 2017), of which 466 were from Lake Butte des Morts and 417 from Lake Winnebago (41 from Monkey Island and 376 from Long Point and Fraction Islands). Of the stomachs sampled from Lake Butte des Morts and Lake Winnebago, 27.2\% (127 of 466) and $39.8 \%$ (166 of 417 ) were empty, respectively. Fourteen different 
prey categories were observed in cormorant diets during the study (Table 2).

Diets of cormorants collected from Lake Butte des Morts consisted primarily of yearling and adult freshwater drum $(n=66$; range $=119-312 \mathrm{~mm}$; average $=223 \mathrm{~mm} ; S D=48.1$ ) and young of year gizzard shad in 2015 and 2016 ( $n=26$; range = 102-190 mm; average $=143 \mathrm{~mm} ; S D=22.9)$ and yearling gizzard shad in 2017 $(n=32$; range $=135-254 \mathrm{~mm}$; average $=171 \mathrm{~mm}$; SD 26.5). Other prey items contributed to cormorant diets on a more infrequent basis during various sampling periods but typically comprised $<5 \%$ of the diets by weight (Tables 2 and 3). Species composition of cormorant diets varied among sampling periods in 2015 (Wilks' $\Lambda=0.43 ; F_{16}$, $284=9.31 ; p<0.001$ ), 2016 (Wilks' $\Lambda=0.49 ; F_{9,50}=5.60 ; p<0.001$ ) and 2017 (Wilks' $\Lambda=0.71 ; F_{18,224}=9.31 ; p=0.003$ ). In 2015, freshwater drum was present in cormorant diets from all sampling periods, although the proportion of drum was significantly greater in the early- and mid-summer periods than the late-summer period $\left(\mathrm{F}_{2}\right.$, $\left.{ }_{149}=21.71 ; p<0.001\right)$. By contrast, the proportion of gizzard shad was significantly greater during the late-summer sampling period $\left(F_{2}\right.$, ${ }_{149}=79.64 ; p<0.001$ ); no gizzard shad were observed in cormorant diets from the early- and mid-summer periods. A similar trend was observed in 2016, with freshwater drum dominating cormorant diets collected during the mid-summer sampling period $\left(F_{1,58}=57.71\right.$; $p<0.001$ ) and gizzard shad being most prevalent in cormorant diets collected during the late-summer period $\left(F_{1,58}=14.34 ; p=0.004\right)$. Diets were not collected from the early-summer sampling period in 2016, and only three cormorants with non-empty stomachs were sampled from the mid-summer period. A different trend was observed in 2017 , where the proportion of freshwater drum was greatest in the late-summer period $\left(F_{2,124}=9.20 ; p<0.001\right)$ and, although gizzard shad were a dominant prey item, their prevalence in cormorant diets did not vary significantly among sampling periods (Table 3).

Similar to diet dynamics of cormorants from Lake Butte des Morts, cormorant diets collected from Lake Winnebago were dominated by yearling and adult freshwater drum $(n=97$; range $=117-315 \mathrm{~mm}$; average $=257 \mathrm{~mm} ; S D=40.2$ ). Gizzard shad were not observed in diets collected in 2015 and 2016, but yearling gizzard shad were frequently observed in diets collected from Lake Winnebago in 2017 ( $n=26$; range $135-249 \mathrm{~mm}$; average $=175 ; S D=32.4$ ). Overall, cormorants from Lake Winnebago fed on a greater diversity of prey items relative to Lake Butte des Morts, but, outside of gizzard shad

TAB LE 2 Number of non-empty stomachs and percent composition (by wet weight; g) of double-crested cormorant diets collected from Lake Butte des Morts and Lake Winnebago, 2015-2017

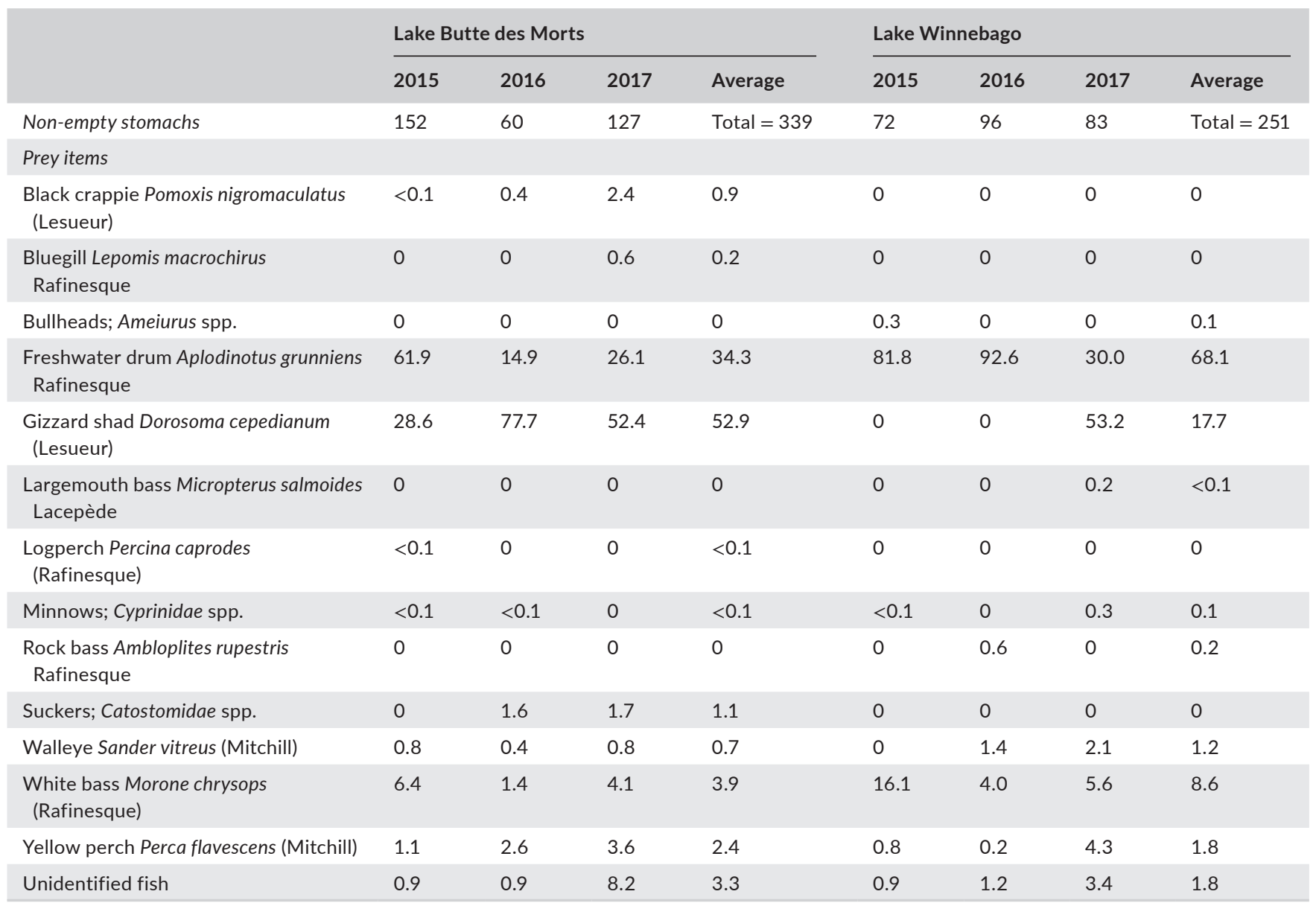

Note: Within lakes and years, column totals sum to $100 \%$. Percentages represent pooled diet composition during April-September of each sampling year. 
TABLE 3 Number of non-empty stomachs (N) and mean percent composition (by wet weight; g) of double-crested cormorant diets collected from Lake Butte des Morts, 2015-2017

\begin{tabular}{|c|c|c|c|c|c|c|c|c|}
\hline Year & Season & $N$ & Freshwater drum & Gizzard shad & Walleye & Yellow perch & White bass & $\begin{array}{l}\text { Other } \\
\text { fish }^{\text {a }}\end{array}$ \\
\hline \multirow[t]{2}{*}{2015} & Early-summer & 53 & 81.1 & 0 & 3.7 & 3.7 & 3.7 & 7.8 \\
\hline & Late-summer & 56 & 36.6 & 60.0 & 0.4 & 1.0 & 0 & 2.0 \\
\hline \multirow[t]{2}{*}{2016} & Early-summer & & & & & & & \\
\hline & Late-summer & 57 & 7.7 & 78.6 & 1.7 & 3.8 & 2.3 & 5.9 \\
\hline \multirow[t]{3}{*}{2017} & Early-summer & 49 & 10.3 & 61.4 & 0 & 1.1 & 3.1 & 24.1 \\
\hline & Mid-summer & 57 & 22.5 & 39.8 & 1.0 & 6.7 & 1.5 & 28.5 \\
\hline & Late-summer & 21 & 50.1 & 33.6 & 0 & 1.0 & 0 & 15.3 \\
\hline
\end{tabular}

Note: The early-summer sampling period consisted of April-May, mid-summer of June-July and late-summer of August-September. Blanks indicate that diets were not sampled in a given year or during a given time period.

${ }^{a}$ Other fish include black crappie, bluegill, bullhead spp., catostomid spp., cyprinid spp., largemouth bass, logperch, rock bass and unidentified fish. Individually, these prey items typically comprised small $(<5 \%)$ proportions of double-crested cormorants by weight.

TAB LE 4 Number of non-empty stomachs (N) and mean percent composition (by wet weight; g) of double-crested cormorant diets collected from Lake Winnebago, 2015-2017

\begin{tabular}{|c|c|c|c|c|c|c|c|c|}
\hline Year & Season & $N$ & Freshwater drum & Gizzard shad & Walleye & Yellow perch & White bass & $\begin{array}{l}\text { Other } \\
\text { fish }^{\mathrm{a}}\end{array}$ \\
\hline \multirow[t]{2}{*}{2015} & Early-summer & 47 & 92.6 & 0 & 0 & 1.0 & 6.0 & 0.4 \\
\hline & Late-summer & 3 & 66.7 & 0 & 0 & 0 & 0 & 33.3 \\
\hline 2016 & Early-summer & 49 & 90.0 & 0 & 2.4 & 0.1 & 2.0 & 5.5 \\
\hline \multirow[t]{3}{*}{2017} & Early-summer & 26 & 22.2 & 60.2 & 0 & 0.9 & 3.8 & 12.9 \\
\hline & Mid-summer & 36 & 57.0 & 12.8 & 2.6 & 6.5 & 0 & 21.1 \\
\hline & Late-summer & 21 & 13.1 & 76.7 & 0 & 2.5 & 7.3 & 0.4 \\
\hline
\end{tabular}

Note: The early-summer sampling period consisted of April-May, mid-summer of June-July and late-summer of August-September. a Other fish include black crappie, bluegill, bullhead spp., catostomid spp., cyprinid spp., largemouth bass, logperch, rock bass and unidentified fish. Individually, these prey items typically comprised small $(<5 \%)$ proportions of double-crested cormorants by weight.

and freshwater drum, these items mostly represented a small $(<5 \%)$ portion of the diets (Tables 2 and 4). Species composition of cormorant diets varied among sampling periods in 2015 (Wilks' $\Lambda=0.57$; $\mathrm{F}_{8,128}=5.16 ; p<0.001$ ) and 2017 (Wilks' $\Lambda=0.51 ; \mathrm{F}_{20,142}=2.86$; $p=0.002$ ), but not in 2016 (Wilks' $\Lambda=0.88 ; \mathrm{F}_{10,176}=9.31 ; p=0.28$ ). In 2015, freshwater drum contributed between 61\% (mid-summer) and $93 \%$ (early-summer) of diets by weight, but the percent contribution did not vary significantly among sampling periods. Rather, overall differences observed in 2015 were related to temporal trends in the prevalence of bullheads Ameiurus spp. The proportion of bullheads in cormorant diets was greater in the late-summer period than in the early- or mid-summer periods $\left(F_{2,69}=16.53\right.$; $p<0.001$; Table 4), but these results were based on only three cormorants with non-empty stomachs sampled from the late-summer period. Gizzard shad was not observed in cormorant diets from any sampling period in 2015 or 2016. In 2017, the proportion of freshwater drum was greatest during the mid-summer sampling period $\left(F_{2}\right.$, ${ }_{80}=8.76 ; p<0.001$; Table 4), whereas gizzard shad was most prevalent in cormorant diets from the early- and late-summer periods $\left(F_{2}\right.$, ${ }_{80}=20.41 ; p<0.001$; Table 4).

Yellow perch was observed in cormorant diets during each year of sampling and was primarily assigned as yearling $(55.0 \%)$ or age-2 (35.0\%) fish based on length ( $n=20$; range $=84-213 \mathrm{~mm}$; mean $=147 \mathrm{~mm} ; S D=44.8$ ). Walleye was also observed in cormorant diets from each year of sampling, and mostly assigned back to young of year $(20.0 \%)$ or yearling $(60.0 \%)$ fish based on length $(n=5$; range $=152-587 \mathrm{~mm}$; average $=233 \mathrm{~mm} ; \mathrm{SD}=49.9)$. Yellow perch constituted an average of $2.4 \%$ (range $=1.1 \%-3.6 \%$ ) and $1.8 \%$ (range $=0.2 \%-4.3 \%$ ) of cormorant diets by weight in lakes Butte des Morts and Winnebago, respectively. Walleye constituted an average 
TABLE 5 Catch per effort (number of fish/trawl) for various life stages (YOY represents young of year) of freshwater drum, white bass, walleye, yellow perch and gizzard shad captured during autumn bottom trawl assessments conducted on Lake Winnebago between 2014-2017
FIGURE 2 Year-class strength of walleye (solid bars) and yellow perch (white bars with black lines) observed through capture of young of year during autumn bottom trawl surveys conducted on Lake Winnebago (1986-2017)

\begin{tabular}{|lrrrr|}
\hline & 2014 & 2015 & 2016 & 2017 \\
\hline YOY freshwater drum & 14.2 & 15.7 & 93.0 & 50.8 \\
\hline $\begin{array}{l}\text { Yearling and older freshwater } \\
\text { drum }\end{array}$ & 443.5 & 691.3 & 491.7 & 734.5 \\
\hline YOY white bass & 0.2 & 4.3 & 17.6 & 7.4 \\
\hline Yearling and older white bass & 2.8 & 4.0 & 2.7 & 3.2 \\
\hline YOY walleye & 0.4 & 1.4 & 9.9 & 4.1 \\
\hline Yearling walleye & 4.2 & 0.8 & 0.8 & 7.3 \\
\hline Age 2 and older walleye & 2.5 & 6.0 & 3.9 & 1.7 \\
\hline YOY yellow perch & 0.1 & 0.7 & 2.3 & 0.8 \\
\hline Yearling yellow perch & 0.7 & 0.1 & 0.3 & 10.0 \\
\hline Age 2 and older yellow perch & 0.9 & 0.3 & 0.1 & 0.6 \\
\hline YOY gizzard shad & 11.4 & 11.7 & 102.4 & 1.3 \\
\hline
\end{tabular}

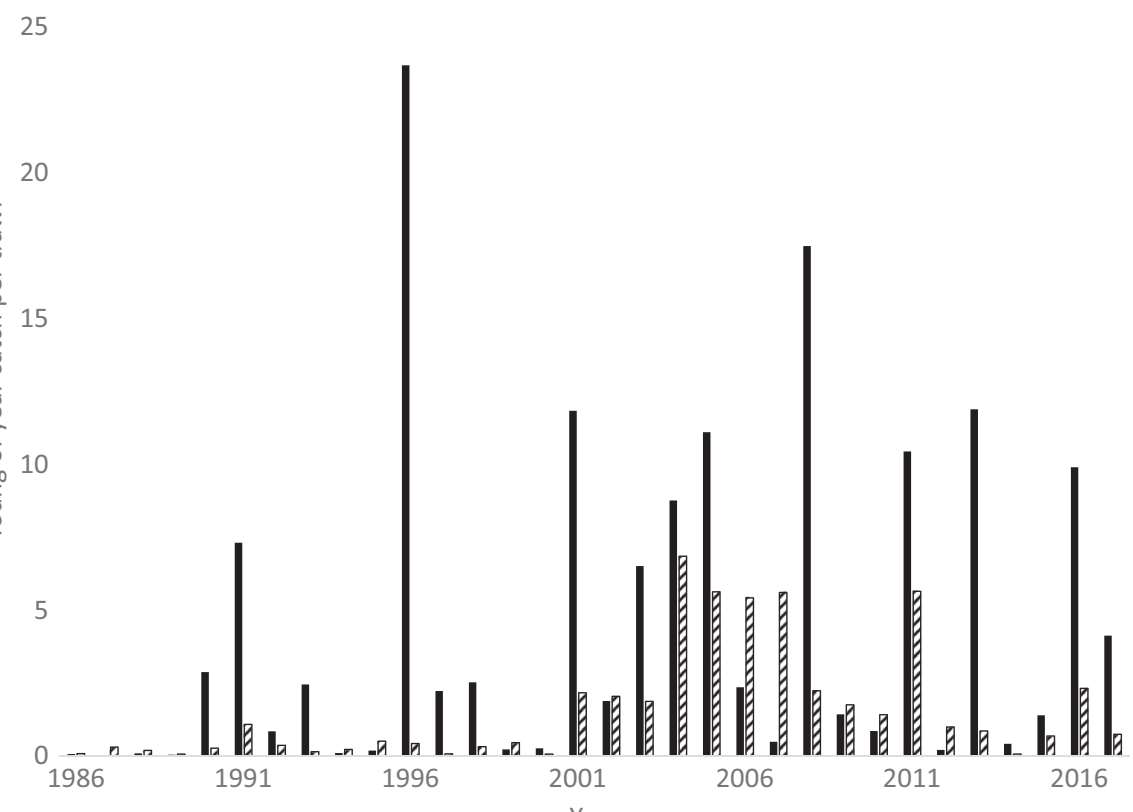

of $0.7 \%$ (range $=0.4 \%-0.8 \%$ ) and $1.2 \%$ (range $=0.0 \%-2.1 \%$ ) of cormorant diets by weight from lakes Butte des Morts and Winnebago, respectively (Table 2 ).

The breeding colony of cormorants was estimated to consume $54,590-130,806 \mathrm{~kg}$ of fish from Lake Butte des Morts in 2015, $48,030-115,089 \mathrm{~kg}$ in 2016 and 64,640-154,889 kg in 2017. The breeding colony of cormorants on Lake Winnebago is smaller than on Lake Butte des Morts, thus producing lower consumption estimates (2015:20,101-48,165 kg; 2016:13,224-31,688 kg; 2017:41,682-99,879 kg).

Cormorants consumed an average of 145,837-349,450 freshwater drum from Lake Butte des Morts and 136,437-326,925 freshwater drum from Lake Winnebago during the three-year study period. These estimates equate to 41-98 fish/ha on Lake Butte des Morts and 2-6 fish/ha on Lake Winnebago. Comparatively, cormorants consumed an average of 645,027-1,545,591 gizzard shad per year (180-431 fish/ha) from Lake Butte des Morts and 76,663-183,697 gizzard shad per year (1-3 fish/ha) from Lake Winnebago. Estimated consumption of yellow perch averaged 20,850-49,961 fish/year (6-14 fish/ha) on Lake Butte des Morts and 10,261-24,586 fish/ year (0.2-0.4 fish/ha) on Lake Winnebago and estimated consumption of walleye on Lake Butte des Morts and Lake Winnebago averaged 3,800-9,105 fish/year (1-2 fish/ha) and 3,329-7,976 fish/year (0.06-0.1 fish/ha), respectively.

Yearling and adult freshwater drum $(n=5,159$; range $=152-$ $592 \mathrm{~mm}$; mean $=290 \mathrm{~mm} ; S D=40.0$ ) dominated the catch in fall bottom trawl assessments conducted on Lake Winnebago in each year of sampling (2014-2017; Table 5). The catch rate of young of year gizzard shad was high in 2016, while lower catch rates observed during 2014, 2015, and 2017 assessments indicated weaker year classes (Table 5). Trawl-based catch rates of young of year walleye and yellow perch were low in 2014 and 2015 relative to other sampling years (Figure 2). However, stronger year classes of both walleye and yellow perch were observed in 2016 (Figure 2), which were 
observed through increased catch rates of young of year percids in 2016 and yearling percids in 2017 (Table 5). Bottom trawl catch rates on Lake Winnebago from 2014-2017 translated into a conservative mean density estimate of 1,326 yearling and adult freshwater drum/ ha (996-1,645 fish/ha; SD = 323.6), 71 young of year gizzard shad/ ha (3-230 fish/ha; $S D=106.4), 16$ young of year and yearling walleye/ha (5-26 fish/ha; SD = 10.2), and 7 yearling and adult (age-2 and older) yellow perch/hectare (1-24 fish/ha; $S D=11.1$ ).

\section{DISCUSSION}

Yearling and adult freshwater drum and young of year and yearling gizzard shad were the primary prey items observed in cormorant diets during the study period. The Lake Winnebago System is a eutrophic waterbody with an abundant and stable population of freshwater drum (Davis-Foust et al., 2009) that provides a yearround, easily accessible food source for cormorants. Gizzard shad is a prolific spawner and exhibits boom-or-bust recruitment cycles as exemplified by a strong year class observed in 2016 and weaker year classes in 2014, 2015 and 2017. Thus, it is not surprising these two readily abundant species dominate cormorant diets. Various other studies conducted throughout the Great Lakes basin have reported similar results as abundant non-sport fish species, including gizzard shad (Coleman et al., 2016; Meadows, 2007), alewife (Seefelt \& Gillingham, 2008) and round goby (DeBruyne et al., 2017; Johnson et al., 2010), have contributed the majority of prey biomass observed in cormorant diets at least seasonally or within a year. These studies, along with the present, demonstrate the opportunistic feeding strategy exhibited by cormorants and how abundant non-sport fish species can buffer impacts of cormorant predation on sportfish species.

Seasonal trends in cormorant diets were apparent for both water bodies during the study. In general, on Lake Butte des Morts, freshwater drum were the predominant forage item during early- and mid-summer, while young of year gizzard shad were more prominent in samples collected late-summer. Diet data from 2015 and 2016 followed this trend, but 2017 was an exception when gizzard shad strongly contributed to cormorant diets during all sampling periods. The life stage of shad observed in cormorant diets may explain the difference between years. All gizzard shad observed in 2015 and 2016 cormorant diets were young of year, while shad observed in 2017 were mostly yearlings. Data collected from the bottom trawl assessment indicated a strong gizzard shad hatch in Lake Winnebago in 2016 (Table 5), and the hatch likely was system-wide, thus the influx of young of year shad in cormorant diets in 2016 and yearling shad in 2017.

Cormorant diets collected from Lake Winnebago in 2015 and 2016 contained mostly freshwater drum throughout all three sampling periods. No gizzard shad was observed in cormorant stomachs collected in 2015 or 2016; however, it is speculated that gizzard shad would have been found in cormorant stomachs had birds been sampled from Lake Winnebago later in the summer. Birds were still present, but it was not possible to collect adequate samples sizes from Lake Winnebago during the post-nesting phase as the birds scattered when approached. Seasonal trends in cormorant diets observed herein are similar to those reported by Bur et al. (1997), where cormorant diets from Lake Erie consisted mainly of freshwater drum in spring and young of year gizzard shad from July-October. Other studies observed sportfish, notably yellow perch, contributed to cormorant diets during early-summer spawning periods before diets shifted to non-sport fish species, such as alewife, gizzard shad and sticklebacks (Belyea, 1997; Diana et al., 2006; Johnson et al., 2002).

The contribution of sportfish to cormorant diets observed during this study was relatively low. Only six black crappies and two bluegill were observed; thus, total consumption for these species was not estimated. Meanwhile, yellow perch was observed in cormorant diets from both waters in each of the three years of sampling, and walleye was observed in each of three years on Lake Butte des Morts and 2 out of 3 years on Lake Winnebago. Despite a greater prevalence than centrarchid species, percids still comprised a relatively small percentage of cormorant diets in each year of sampling for both lakes. Conversely, Schultz et al. (2013) noted that percids were a dominant prey item in cormorant diets from Leech Lake, Minnesota. Rudstam et al. (2004) reported similar results and concluded that cormorant predation was a major factor contributing to the decline in walleye and yellow perch populations in Oneida Lake, New York. However, follow-up research from Oneida Lake observed that cormorant diet composition was strongly impacted by year-class strength of various fish species and that cormorant diets would shift away from percids following strong year classes of non-sport fish species like gizzard shad, white perch Morone americana (Gmelin), emerald shiner Notropis atherinoides Rafinesque and freshwater drum (Coleman et al., 2016). These studies demonstrate how cormorant diets can vary among and within waterbodies from year to year depending on the fish community present. Year-class strength of gizzard shad and other sport and non-sportfish fish may be variable from year to year on the Lake Winnebago System, but the adult freshwater drum population is relatively stable and provides a consistent buffer against cormorant predation on percids.

Although cormorants consume a large amount of biomass per year, the present results suggest that cormorant predation removes a relatively small proportion of the available sportfish within Lake Winnebago. Cormorant predation accounted for $<1 \%$ of the standing crop of yearling and adult freshwater drum and fingerling and yearling walleye, even when assuming the upper estimate of daily consumption. Consumption of the standing crop of yearling and age- 2 and older yellow perch were higher, but still $<5 \%$ in two of the three years of the study. Further, the estimates of fish density from bottom trawl assessments on Lake Winnebago are conservative given that sampling was only in the bottom $0.5-1.0 \mathrm{~m}$ of the water column and gear avoidance was not determined.

The average number of feeding days per hectare on Lake Winnebago was lower than reported for Leech Lake, Minnesota (Schultz et al., 2013) and Oneida Lake, New York (Coleman et al., 2016). However, cormorant feeding pressure on Lake Butte des Morts was $14 x$ higher than reported for Oneida Lake, New York, 
and 4x higher than reported for Leech Lake, Minnesota (Schultz et al., 2013). Further, the current estimates of cormorant consumption (number of fish/ha) were $32 \mathrm{x}$ higher for yellow perch and $18 \mathrm{x}$ higher for walleye on Lake Butte des Morts relative to Lake Winnebago. The potential impacts of cormorant predation on the fish community within Lake Butte des Morts are difficult to evaluate because fish density data are not available. Further research is needed to evaluate the influence of cormorant predation on fish communities in Lake Butte des Morts, which has a larger breeding colony of cormorants, yet smaller surface area than Lake Winnebago.

Consumption estimates by waterbody hinge on the assumption that cormorants are only feeding in the waterbody where they are nesting. For example, it was assumed that the breeding colony of cormorants on Lake Butte des Morts only feeds within Lake Butte des Morts proper. Although some studies reported that cormorants feed in relatively close proximity to roosting sites $(<5 \mathrm{~km}$; Coleman et al., 2005; Seefelt \& Gillingham, 2006), others reported substantially greater foraging distances ( $>40$ km; Ainley et al., 1990; Custer \& Bunck, 1992). This is particularly important to note given that cormorants nesting on Lake Butte des Morts are in close proximity $(<15 \mathrm{~km})$ to lakes Winnebago, Winneconne and Poygan along with the upper Fox and Wolf rivers (Figure 1). Although foraging distance was not measured, cormorants were observed throughout the Lake Winnebago System, not just on lakes Winnebago and Butte des Morts, and are likely feeding throughout the system. If cormorants are feeding outside of their nesting water body, consumption estimates may be lower than currently estimated. Mean annual cormorant consumption estimates equate to $0.5-1.1$ yellow perch/ha and 0.1-0.3 walleye/ha when factoring in the combined areas of Lakes Winnebago, Butte des Morts, Winneconne and Poygan. Thus, it is plausible that cormorants may have localised impacts (i.e. near nesting colonies) on the fish community within the Lake Winnebago System, particularly on Lake Butte des Morts, but there does not appear to be a system-wide effect on any species, at least at the current cormorant abundance and fish community assemblage.

Cormorant colony size was reduced on Lake Winnebago and Lake Butte des Morts during the time of this study, largely due to management actions. Because cormorant diets were not collected during years of peak abundance, the impact of cormorant predation on sportfish populations during those years is largely unknown. However, applying cormorant diet data collected during 2015-2017 to peak cormorant numbers observed in 2008 (Lake Winnebago) and 2014 (Lake Butte des Morts) could provide insight to the relative influence of cormorant predation during those years. Considering the mean percent contribution of yellow perch and walleye to cormorant diets during 2015-2017 and peak observed cormorant abundance, the number of yellow perch and walleye consumed would have been 2.8 and 2.3 times higher on Lake Butte des Morts and 7.0 and 8.7 times higher on Lake Winnebago. While it is likely that the influence of cormorant predation on sportfish populations during years of peak abundance was greater than observed between 2015-2017, this retrospective analysis should be viewed as speculative as it is difficult to estimate the actual magnitude of predation in the absence of temporally aligning cormorant diet and fishery data. Tracking colony size is imperative to understanding the impact of cormorant predation on sportfish populations and managers may need to re-evaluate the influence of cormorant predation in the future if colony size increases substantially.

The present analysis made several assumptions that may have influenced estimates of total and prey fish-specific consumption, as well as the potential influence of cormorant predation on fish populations throughout the Lake Winnebago System. Most notably, daily ingestion rates for cormorants in the Lake Winnebago System were not estimated but applied daily ingestion rates reported from other studies (Meadows, 2007; Schultz et al., 2013). Any biases associated with this method were tempered by using minimum and maximum daily ingestion rates reported in the literature to estimate a likely range in consumption rather than estimating a single nominal value. Nonetheless, the ranges of consumption estimates were relatively large, which may have reduced our ability to determine the influence of cormorant predation on prey fish populations. However, even when consumption estimates were based on the maximum reported daily ingestion rate, the influence of cormorant predation on fish communities in the Lake Winnebago System appears to be relatively small. Future research incorporating system-specific ingestion rates may help to refine consumption estimates and the influence of predation. A second important assumption was that consumption estimates were only based on the breeding population of cormorants. Egg oiling has substantially reduced recruitment of cormorants, thus minimising any potential impacts of predation by immature birds (USDA WS, unpublished data) and likely reducing consumption by adults as they do not have to feed developing young. The number of migrant and non-breeding birds is not included in standard protocols (Cuthbert \& Wires, 2013) used to estimate cormorant abundance in the Lake Winnebago System, but the overall impact is believed to be minimal relative to the total consumption from the nesting colony (Personal communication, Wildlife Services). Furthermore, migrant cormorants are only present for a short period in the spring and fall and a diet shift towards sportfish in diets collected during either of those time periods was not observed. Consequently, the influence of migrant and non-breeding cormorants on sportfish consumption in the Lake Winnebago System is likely minimal. This assumption is further supported by the findings of Schultz et al., (2013), who reported that non-breeding and transient cormorants had minimal effects on overall cormorant consumption estimates in Leech Lake, Minnesota. When considering the analytical approach and the aforementioned assumptions, conservative estimates of consumption were compared with conservative estimates of prey fish availability from bottom trawl assessments. Thus, it is posited that conclusions made regarding the relative influence of cormorant predation on fish communities in the Lake Winnebago System remain valid.

Although the results demonstrated that cormorants can annually remove a large biomass of fish from the Lake Winnebago System, the potential influence of cormorant predation on yellow perch and walleye populations appears to be buffered by an abundant population of freshwater drum and periodic strong year 
classes of gizzard shad. Specifically, under current conditions relative to cormorant population abundance, feeding habits and trends in year-class strength of yellow perch, walleye and potential buffer species (i.e. freshwater drum and gizzard shad), cormorant predation does not appear to be a substantial factor limiting recruitment or abundance of yellow perch or walleye in the Lake Winnebago System. Nonetheless, cormorants demonstrate adaptive foraging behaviours and can rapidly switch to newly abundant prey species (e.g. Johnson et al., 2010), suggesting that the influence of cormorant predation is not static and will likely fluctuate depending on prevailing biotic and abiotic conditions that influence cormorant and prey species population structure and abundance. Continual monitoring may be needed to assess further long-term impacts of cormorant predation on the Lake Winnebago System sportfish community, particularly if cormorant populations increase substantially in the future or if drastic changes are observed within the fish community.

\section{ACKNOWLEDGEMENTS}

We thank all current and former DNR staff who assisted with collection of cormorant diet data, particularly J. Kohls, Z. Snobl and A. O'Connell. We also thank all Wildlife Services staff who assisted with cormorant collection and nest counts, particularly $M$. Jones, S. Krueger and M. Burg. D. Schultz and B. Doerr provided helpful comments on an earlier draft of the manuscript. This research was funded by a grant awarded from the Great Lakes Restoration Initiative. Any use of trade, firm, or product names is for descriptive purposes only and does not imply endorsement by the U.S Government.

\section{DATA AVAILABILITY STATEMENT}

Data available on request from the authors.

\section{ORCID}

Ryan P. Koenigs (ID https://orcid.org/0000-0002-0841-4545

\section{REFERENCES}

Ainley, D. G., Strong, C. S., Penninman, T. M., \& Boekelheide, R. J. (1990). The feeding ecology of Farallon seabirds. In D. G. Ainley, \& R. J. Boekelheide (Eds.), Seabirds of the Farallon Islands: Ecology, dynamics and structure of an upwelling-system community (pp. 51-127). Stanford University Press.

Belyea, G. Y. (1997). The impact of cormorant predation on yellow perch in the Les Cheneaux Islands, Lake Huron. In J. S. Diana, G. Y. Belyea, \& R. D. Clark(Eds.), History, status, and trends in populations of yellow perch and double-crested cormorants in Les Cheneaux Islands, Michigan (pp. 42-46). Michigan Department of Natural Resources Special Report 17. : Michigan Department of Natural Resources.

Bur, M. T., Tinnierello, S. L., Lovell, C. D., \& Tyson, J. T. (1997). Diet of the double-crested cormorant in western Lake Erie. In M. E. Tobin (Ed.), Symposium on double-crested cormorants: population status and management issues in the Midwest (pp. 73-85). : USDA-APHIS Technical Bulletin 1879

Campo, J. J., Thompson, C., Barron, J. C., Telfair, R. C. III, Durocher, P., \& Gutreuter, S. (1993). Diet of double-crested cormorants wintering in Texas. Journal of Field Ornithology, 64, 135-144.
Chipps, S. E., \& Garvey, J. E. (2007). Assessment of diets and feeding patterns. In C. S. Guy, \& M. L. Brown (Eds.), Analysis and interpretation of freshwater fisheries data (pp. 473-514). American Fisheries Society.

Coleman, J. T. H., Adams, C. M., Kandel, M., \& Richmond, M. E. (2012). Eating the invaders: The prevalence of round goby (Apollonia melanostomus) in the diet of double-crested cormorants on the Niagara River. Waterbirds, 35, 103-113.

Coleman, J. T. H., DeBruyne, R. L., Rudstam, L. G., Jackson, J. R., VanDeValk, A. J., Brooking, T. E., Adams, C. M., \& Richmond, M. E. (2016). Evaluating the influence of double-crested cormorants on walleye and yellow perch populations in Oneida Lake, New York. In L. G. Rudstam, E. L. Mills, J. R. Jackson, \& D. J. Stewart (Eds.), Oneida Lake: Long-term dynamics of a managed ecosystem and its fishery ( $\mathrm{pp}$. 397-426). American Fisheries Society.

Coleman, J. T. H., Richmond, M. E., Rudstam, L. G., \& Mattison, P. M. (2005). Foraging location and site fidelity of the double-crested cormorant on Oneida Lake, New York. Waterbirds, 28, 498-510.

Cook, C., \& Neiswender, C. (2007). The economic impact of angling on the Lake Winnebago system. University of Wisconsin Extension.

Craven, S. R., \& Lev, E. (1987). Double-crested cormorants in the Apostle Islands, Wisconsin, USA: Population trends, food habits, and fishery depredation. Colonial Waterbirds, 10, 64-71.

Custer, T. W., \& Bunck, C. (1992). Feeding flights of breeding double-crested cormorants at two Wisconsin colonies. Journal of Field Ornithology, 63, 203-211.

Cuthbert, F. J., \& Wires, L. (2013). The fourth decadal U.S. Great Lakes colonial waterbird survey (2007-2010): Results and recommendations to improve the scientific basis for conservation and management. Final Report to the U.S. Fish and Wildlife Service, Fort Snelling: .

Davis-Foust, S. L., Bruch, R. M., Campana, S. E., Olynyk, R. P., \& Janssen, J. (2009). Age validation of freshwater drum using bomb radiocarbon. Transactions of the American Fisheries Society, 138, 385-396.

DeBruyne, R. L., Fielder, D. G., Roseman, E. F., \& Butchko, P. H. (2017). Exploring potential effects of cormorant predation on the fish community in Saginaw Bay, Lake Huron. Journal of Great Lakes Research, 43, 387-393.

Diana, J. S., Maruca, S., \& Lowe, B. (2006). Do increasing cormorant population threaten sport fishes in the Great Lakes? A case study in Lake Huron. Journal of Great Lakes Research, 32, 306-320.

Fielder, D. G. (2008). Examination of factors contributing to the decline of the yellow perch population and fishery in Les Cheneaux Islands, Lake Huron, with emphasis on the role of double-crested cormorants. Journal of Great Lakes Research, 34, 506-523.

Fielder, D. G. (2010). Response of yellow perch in the Les Cheneaux Islands, Lake Huron to declining numbers of double-crested cormorants stemming from control activities. Journal of Great Lakes Research, 36, 207-214.

Johnson, J. H., McCullough, R. D., Farquhar, J. F., \& Mazzocchi, I. (2015). Little Galoo Island, Lake Ontario: Two decades of studies on the diet, fish consumption, and management of double-crested cormorants. Journal of Great Lakes Research, 41, 652-658.

Johnson, J. H., Ross, R. M., \& McCullough, R. D. (2002). Little Galoo Island, Lake Ontario: A review of nine years of double-crested cormorant diet and fish consumption information. Journal of Great Lakes Research, 28, 182-192.

Johnson, J. H., Ross, R. M., McCullough, R. D., \& Mathers, A. (2010). Diet shift in double-crested cormorants in eastern Lake Ontario associated with the expansion of the invasive round goby. Journal of Great Lakes Research, 36, 242-247.

King, L. E., de Solla, S. R., Marentette, J. R., Lavoie, R. A., Kyser, T. K., Campbell, L. M., Arts, M. T., \& Quinn, J. S. (2017). Fatty acids, stable isotopes, and regurgitate reveal diet differences between Lake Ontario and Lake Erie double-crested cormorants (Phalacrocorax auritus). Journal of Great Lakes Research, 43, 132-140. 
Koenigs, R. P., Bruch, R. M., Stelzer, R. S., \& Kamke, K. K. (2015). Validation of otolith ages for walleye (Sander vitreus) in the Winnebago system. Fisheries Research, 167, 13-21.

Meadows, S. A. (2007). Food habits of double-crested cormorants in southern Green Bay with emphasis on impacts on the yellow perch fishery. Final summary report prepared for the Wisconsin Department of Natural Resources. University of Wisconsin.

Ross, R. M., \& Johnson, J. H. (1997). Fish losses to double-crested cormorant predation in eastern Lake Ontario. In M. E. Tobin (Ed.), Symposium on double-crested cormorants: population status and management issues in the Midwest (pp. 61-70). : USDA-APHIS Technical Bulletin 1879.

Rudstam, L. G., VanDeValk, A. J., Adams, C. M., Coleman, J. T. H., Forney, J. L., \& Richmond, M. E. (2004). Cormorant predation and the population dynamics of walleye and yellow perch in Oneida Lake. Ecological Applications, 14, 149-163.

Schultz, D. W., Carlson, A. J., Mortensen, S., \& Pereira, D. L. (2013). Modeling population dynamics and fish consumption of a managed double-crested cormorant colony in Minnesota. North American Journal of Fisheries Management, 33, 1283-1300.

Seefelt, N. E., \& Gillingham, J. C. (2006). Foraging locations of double-crested cormorants in the Beaver Archipelago of northern Lake Michigan: Potential for impacts on smallmouth bass. Waterbirds, 29 , 473-480.

Seefelt, N. E., \& Gillingham, J. C. (2008). Bioenergetics and prey consumption of breeding double-crested cormorants in the Beaver Archipelago, Northern Lake Michigan. Journal of Great Lakes Research, 34, 122-133.
Shwiff, S., Kirkpatrick, K., \& DeVault, T. (2009). The economic impact of double-crested cormorants to central New York. National Wildlife Research Center.

VanDeValk, A. J., Adams, C. M., Rudstam, L. G., Forney, J. L., Brooking, T. E., Gerken, M. A., Young, B. P., \& Hooper, J. T. (2002). Comparison of angler and cormorant harvest of walleye and yellow perch in Oneida Lake, New York. Transactions of the American Fisheries Society, 131, 27-39.

Weseloh, C., Pekarik, C., Havelke, T., Barrett, G., \& Reid, J. (2002). Population trends and colony locations of double-crested cormorants in the Canadian Great Lakes and immediately adjacent areas, 1990-2000: A manager's guide. Journal of Great Lakes Research, 28, 125-144

Wires, L. R., \& Cuthbert, F. J. (2006). Historic populations of the double-crested cormorant (Phalacrocorax auritus): Implications for conservation and management in the $21^{\text {st }}$ century. Waterbirds, 29 , 9-37.

How to cite this article: Koenigs RP, Dembkowski DJ, Lovell CD, Isermann DA, Nickel AD. Diets of double-crested cormorants in the Lake Winnebago System, Wisconsin. Fish Manag Ecol. 2021;28:183-193. https://doi.org/10.1111/ fme.12466 